\title{
Performance of super-absorbent polymer as an internal curing agent for self-compacting concrete
}

\author{
Suhair Al-Hubboubi ${ }^{1, *}$, Tareq al-Attar ${ }^{2}$, Haider Al-Badry ${ }^{1}$, Samir Abood ${ }^{3}$, Rawaa Mohammed ${ }^{1}$ and Buthaina \\ Haddhood $^{1}$ \\ ${ }^{1}$ Building Research Directorate, Iraq \\ ${ }^{2}$ University of Technology, Iraq \\ ${ }^{3}$ Al-Mutasim State Company for Construction Contracts, Iraq
}

\begin{abstract}
Internal curing agent by using super-absorbent polymer was present in this study, its effect on the properties of self-compacting concrete was evaluated .The SAP content in the concrete mix was $0.5 \%$ by weight of cement. Three procedures for curing were adopted; curing in water, curing in water and air and curing in polyethylene sealed bags. Fresh concrete tests conducted to assess the self-compactability of the produced concrete. Moreover, compressive and splitting strength tests were carried out. The testing program had been extended to the age of 90 days. The use of super-absorbent polymer did not affect the fresh state characteristics of the studied SCC and achieved an increase in both compressive and tensile strengths as compared to the reference concrete mix.
\end{abstract}

\section{Introduction}

Okamura [1] defined Self-Compacting Concrete (SCC) as concrete that is able to flux in the interior of the formwork, flow in a natural manner and then pass through the reinforcing bars and other obstacles under the action of its own weight .In order to achieve the required flowability, high strength concrete and low water to cementitious materials ratio $(\mathrm{w} / \mathrm{cm})$, high-range water reducer (HRWR) admixtures are essential [2]. Self-desiccation will arise with mixtures having low water-cementitious materials ratios $(w / \mathrm{cm})$ [3].The aim of internal curing is to prevent self-desiccation and the accompanying autogenous stresses and strains that may lead to early age cracking by maintaining saturated conditions within a hydrated cement paste

The efficiency of internal curing, preserve saturated conditions within a hydrating cement paste in order to avoid self-desiccation and the accompanying autogenous stresses and strains that may lead to early age cracking. depending on the measurement of a wide sets of performance properties like restrained shrinkage internal relative humidity, restrained shrinkage and creep, degree of hydration, and compressive strength development ,the efficiency has been estimated for the internal curing for example by using saturated lightweight aggregates (LWA) or super-absorbent polymers (SAP) [4-7].

Super-absorbent polymers (SAP) are generally white sugar-like hygroscopic materials also SAP are hydrophilic networks that can absorb and retain large amounts of water or aqueous solutions. [8]. Superabsorbent polymers made from partially neutralized, lightly cross-linked poly (acrylic acid) are proved to give the best performance versus cost ratio. Dried polymers are milled in to granular white solids while in water they swell to a rubbery gel that in some cases can be up to 99\% water. These polymers are manufactured at low solids levels for both quality and economic reasons [9]. Very efficient internal water curing can be ensured by using SAP, which is defined as "incorporation of a curing agent serving as an internal reservoir of water, gradually releasing it as the concrete dries out [10]. From a strength point of view, there are two opposite effects for the addition of SAPs to concrete, first it generates voids in the concrete and thus reduces strength;second enhances the degree of hydration due to the internal water curing provided by the SAP and that way increases the strength. Water-cement ratio $(\mathrm{w} / \mathrm{c})$, the maturity of the concrete, and the amount of SAP addition determines which of these two effects is dominant depends on the water-cement ratio (w/c), the maturity of the concrete, and the amount of SAP addition. The total effect seems to be described well with existing models, such as the gel-space ratio concept. In particular, at a high w/c (more than 0.45 ), also there is very little effect on hydration through the addition of SAP which generally reduces compressive strength. At a low w/c (less than 0.45), SAP addition may increase the compressive strength [11].

\section{Material and Experimental work}

\subsection{Materials}

Cement: In all types of concrete mixes Portland cement conforming to IQS No. 5/1984- type I [12], was used. Tables 1 and 2 show the chemical and physical properties of the cement 
Table 1. Chemical properties of cement

\begin{tabular}{|c|c|c|c|}
\hline $\begin{array}{l}\text { Compound } \\
\text { composition }\end{array}$ & $\begin{array}{l}\text { Abbre- } \\
\text { viation }\end{array}$ & $\begin{array}{l}\text { Percent by } \\
\text { weight }\end{array}$ & $\begin{array}{c}\text { Limit of } \\
\text { IQS } \\
\text { No.5/1984 }\end{array}$ \\
\hline Lime & $\mathrm{CaO}$ & 62.02 & - \\
\hline Silica & $\mathrm{SiO}_{2}$ & 21.13 & - \\
\hline Alumina & $\mathrm{Al}_{2} \mathrm{O}_{3}$ & 5.33 & - \\
\hline Iron oxide & $\mathrm{Fe}_{2} \mathrm{O}_{3}$ & 3.07 & - \\
\hline Magnesia & $\mathrm{MgO}$ & 1.71 & $\leq 2.85 \%$ \\
\hline Sulfate & $\mathrm{SO}_{3}$ & 2.65 & $\leq 5 \%$ \\
\hline Loss on ignition & L.O.I & 4 & $\leq 4 \%$ \\
\hline $\begin{array}{c}\text { Insoluble } \\
\text { residue }\end{array}$ & I.R & 1.04 & $\leq 1.5$ \\
\hline $\begin{array}{l}\text { Lime saturation } \\
\text { factor }\end{array}$ & L.S.F & 0.88 & $0.66-1.02$ \\
\hline \multicolumn{4}{|c|}{ Main compounds $\%$ by weight } \\
\hline Compounds & $\begin{array}{l}\text { Abbrevia } \\
\text { tion }\end{array}$ & \multicolumn{2}{|c|}{ Percent by weight } \\
\hline $\begin{array}{c}\text { Tri calcium } \\
\text { silicate }\end{array}$ & $\mathrm{C}_{3} \mathrm{~S}$ & \multicolumn{2}{|c|}{44} \\
\hline $\begin{array}{c}\text { Di calcium } \\
\text { silicate }\end{array}$ & $\mathrm{C}_{2} \mathrm{~S}$ & \multicolumn{2}{|c|}{27.6} \\
\hline $\begin{array}{c}\text { Tri calcium } \\
\text { laminate }\end{array}$ & $\mathrm{C}_{3} \mathrm{~A}$ & \multicolumn{2}{|c|}{8.9} \\
\hline $\begin{array}{l}\text { Tetra calcium } \\
\text { alumino ferrite }\end{array}$ & $\mathrm{C}_{4} \mathrm{AF}$ & \multicolumn{2}{|c|}{9.3} \\
\hline
\end{tabular}

Table 2. Physical properties of cement

\begin{tabular}{|c|c|c|}
\hline Physical properties & $\begin{array}{c}\text { Limits } \\
\text { of } \\
\text { cement }\end{array}$ & $\begin{array}{c}\text { Limits of IQS No. } \\
\mathbf{5 / 1 9 8 4}\end{array}$ \\
\hline Fineness m2/kg & 340.2 & $\geq 230$ \\
\hline Initial setting time (h:min) & $1: 40$ & $\geq 00: 45$ \\
\hline Final setting time (h:min) & $4: 15$ & $\leq 10: 00$ \\
\hline Compressive strength(Mpa) & & \\
3 days & 33 & $\geq 15$ \\
7 days & 39 & $\geq 23$ \\
\hline
\end{tabular}

Table 3. Gradation of fine aggregate

\begin{tabular}{|c|c|c|}
\hline Sieve size (mm) & $\begin{array}{c}\text { Percentage } \\
\text { passing \% }\end{array}$ & $\begin{array}{c}\text { Limit of IQS } \\
\text { No.45/1980, zone( 2) }\end{array}$ \\
\hline 10 & 100 & 100 \\
\hline 4.75 & 90 & $90-100$ \\
\hline 2.36 & 74.5 & $75-90$ \\
\hline 1.18 & 63 & $55-90$ \\
\hline 0.6 & 44.4 & $35-55$ \\
\hline 0.3 & 14.8 & $8-30$ \\
\hline 0.15 & 3 & $0-10$ \\
\hline Sulfite \% (SO3) & 0.047 & $\leq 0.5 \%$ \\
\hline
\end{tabular}

Table 4. Gradation of coarse aggregate

\begin{tabular}{|c|c|c|}
\hline $\begin{array}{c}\text { Sieve } \\
\text { size(mm) }\end{array}$ & $\begin{array}{c}\text { Percentage passing } \\
\mathbf{\%}\end{array}$ & $\begin{array}{c}\text { Limit of Iraqi } \\
\text { specification NO. } \\
\mathbf{( 4 5 / 1 9 8 4 )}\end{array}$ \\
\hline 20 & 100 & 100 \\
\hline 10 & 37 & $30-60$ \\
\hline 5 & 2.8 & $0-10$ \\
\hline $\begin{array}{c}\text { Sulfite } \\
\text { content }\end{array}$ & 0.07 & $\geq 0.1 \%$ \\
\hline
\end{tabular}

Fine aggregate: Natural sand conforming to IQS No.45/1984- Zone 2 was used [13]. Table (3) shows the gradation of the used sand and its main properties.

Coarse aggregate: $20 \mathrm{~mm}$ maximum size of crushed river gravel was used, conforming to Iraqi specification to IQS No.45/1984 [13], and was shown in Table (4).
Silica fume: Silica fume (exported from Elkem material company) is a highly reactive material used in this research as Pozzolanic materials to produce SCC. Silica fume conforms to the ASTM 1240 [14]. Physical and chemical properties for this by-product are listed in Table 5 and 6.

Limestone powder (LSP): Limestone powder (locally known as Al-Gubra). It has been used as filler for concrete production for many years. It was added as $9 \%$ replacement by weight of cementitious materials to enhance the workability of SCC mixes. Chemical properties for this material are listed in Table 7.

High Range Water Reducing Admixture:

Superplasticizer known commercially as (BETONAC ${ }^{\circledR}$ 1030) was used. It conforms to the ASTM C 494- type G. SCC (self-compacting/ consolidating) concrete was produced by designing high efficiency acrylic copolymer-based superplasticizer, with extremely high levels of workability without segregation. The SP content in the concrete mixes was $8.750 \mathrm{Kg} / \mathrm{m} 3$. Its properties (as claimed by the manufacturer ) are listed in Table 8 .

Crushed Brick: Pieces of clay bricks, conforming to IQS No.25/1984-Class B [15], was used. The water absorption for this brick was about $21.16 \%$.The brick was crushed and graded as the grading curve of sand (Zone 2). It was used by two percentages (15 and 20) \% as a partial volumetric replacement of sand. Before using the crushed brick in the mix, it was soaked in water for (24) hours to bring the particles to saturated condition.

Super-absorbent Polymer, SAP: Commercial SAP, white sugar-like was used. It is described as an ionic polyacrylamide and used efficiently in agriculture to reduce watering intervals. SAPs has the ability to gain and preserve aqueous solutions up to several hundred times of its own weight as can be seen in Figure 1. It was added $(0.5 \%)$ by weight of cement. The dry particle of SAP carefully mixed with sand before adding the mixing water.

Table 5. Physical and Chemical Properties of Silica Fume

\begin{tabular}{|c|c|c|}
\hline $\begin{array}{c}\text { Compound } \\
\text { composition }\end{array}$ & Percent by weight & $\begin{array}{c}\text { Limit of ASTM } \\
\text { C1240 }\end{array}$ \\
\hline Loss on ignition & 2.14 & $\leq 6$ \\
\hline $\mathrm{SiO}_{2}$ & 93.47 & $\geq 85$ \\
\hline $\mathrm{Al}_{2} \mathrm{O}_{3}$ & 2.15 & \\
\hline $\mathrm{Fe}_{2} \mathrm{O}_{3}$ & 0.65 & \\
\hline $\mathrm{SO}_{3}$ & $\mathrm{Nil}$ & \\
\hline Total & 99.79 & \\
\hline
\end{tabular}

Table 6. Physical properties of Silica Fume

\begin{tabular}{|c|c|c|}
\hline Physical properties & results & $\begin{array}{c}\text { Requirement of } \\
\text { ASTM C1240 }\end{array}$ \\
\hline $\begin{array}{c}\text { Retaining on sieve } \\
45 \mu \mathrm{m}, \%\end{array}$ & 6 & $\leq 10$ \\
\hline $\begin{array}{c}\text { strength activity } \\
\text { index }\end{array}$ & 125 & $\geq 105$ \\
\hline
\end{tabular}


Table 7. Chemical Properties of LSP

\begin{tabular}{|c|c|}
\hline $\begin{array}{c}\text { Compound } \\
\text { composition }\end{array}$ & Percent by weight \\
\hline Loss on ignition & 43 \\
\hline $\mathrm{SiO}_{2}$ & 1.83 \\
\hline $\mathrm{Al}_{2} \mathrm{O}_{3}$ and $\mathrm{Fe}_{2} \mathrm{O}_{3}$ & 0.63 \\
\hline $\mathrm{SO}_{3}$ & 0.2 \\
\hline $\mathrm{MgO}$ & 0.58 \\
\hline $\mathrm{CaO}$ & 53.71 \\
\hline
\end{tabular}

Table 8. Properties of HRWR

\begin{tabular}{|c|c|}
\hline Chemical content & Polycarboxylate based \\
\hline Color, appearance & transparence \\
\hline $\mathrm{pH}$ & 7.5 at $20^{\circ} \mathrm{c}$ \\
\hline Density & $1.108 \mathrm{~g} / \mathrm{ml}$ \\
\hline
\end{tabular}

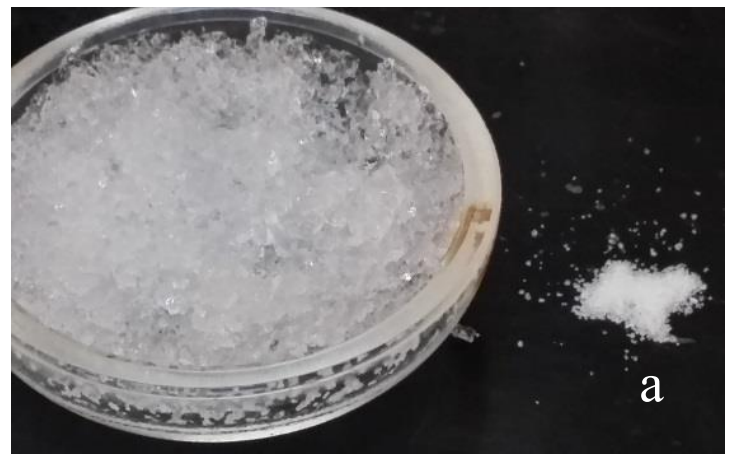

Fig. 1. (a) Dry SAP powder and (b) swollen SAP.

\section{Concrete Mix Proportions}

For the production of SCC, the mix proportioning should be performed so that the predefined properties of the fresh concrete are reached. The total powder content was $500 \mathrm{~kg} / \mathrm{m}^{3}$, consisting of cement $405 \mathrm{~kg} / \mathrm{m}^{3}$, silica fume $50 \mathrm{~kg} / \mathrm{m}^{3}$ and limestone powder $45 \mathrm{~kg} / \mathrm{m}^{3}$. The fine and coarse aggregate contents were (880 and 900) $\mathrm{kg} / \mathrm{m}^{3}$ respectively. Water content was $172 \mathrm{~kg} / \mathrm{m}^{3}$ for reference mix (R) and for mixes containing crushed brick (B 15 and B 20\%). Meanwhile the mix containing $0.5 \%$ SAP had $173 \mathrm{~kg} / \mathrm{m}^{3}$ of water. According to these proportions, the reference mix yielded $60 \mathrm{MPa}$ compressive strength at 28 days. The concrete was mixed using a drum mixer of $50 \mathrm{~L}$ capacity. Mixing procedure followed the laboratory procedure outlined by Emborg [16] as follows: Fine aggregate was added to the mixer with $1 / 3$ of water and mixed for 1-minute following that, the powder mixture of cement, limestone and Silica fume was added. After that, the coarse aggregate was added with the last $1 / 3$ mixing water and $1 / 3$ of superplasticizer, and mixing for 1.5 minutes; then, the remaining $2 / 3$ of the superplasticizer was added and mixed for 1.5 minutes; the mixture was then discharged and cast in moulds.

Curing Procedures

After the demoulding of specimens, three methods of curing were used. The first one was by immersing specimens in tap water until the time of testing (watercured). The second method was by curing the specimens in water for 7 days and then the specimens were put in a wetted burlap bags and all covered with plastic sheet (moist-cured). The last method was by curing the specimens in water for 7 days and then left in laboratory conditions (air-cured).

\section{Experimental Program}

The fresh SCC tests include; the slump flow, L-box. The tests were conducted according to the standard methods cited by international literature [17] and the results were recorded.

Tests for hardened concrete were; compressive strength B.S 1881: Part 116 [18], splitting tensile strength (ASTM C496) [19] and ultrasonic pulse velocity (ASTM C597) [20]. The compressive strength test was done cubes at 7, 28 and 90 days curing age. The splitting strength and UPV tests were done on cylinders at the age of 90 days.

\section{Results and Discussion}

\subsection{Fresh SCC}

Desired fresh properties of SCC include suitable flowability, good passing and filling abilities, isolation resistance and stability, which are achieved by properly proportioning the constituent materials and related admixtures. Table 9 shows the results of fresh SCC tests. The tested concrete has proven itself to have selfcompactability.

Table 9. Fresh Tests results for all fresh mixes.

\begin{tabular}{|c|c|c|c|c|}
\hline \multirow{2}{*}{ Mix } & \multirow{2}{*}{$\begin{array}{c}\text { Details of } \\
\text { replacement }\end{array}$} & \multicolumn{2}{|c|}{ Slump flow } & $\begin{array}{c}\text { L- } \\
\text { Box }\end{array}$ \\
\cline { 3 - 4 } & $\mathbf{D}$ (mm) & $\mathbf{T}_{\mathbf{5 0 0}}(\mathbf{s e c})$ & $\begin{array}{c}\text { H1/ } \\
\text { H2 }\end{array}$ \\
\hline Ref & $\begin{array}{c}\text { No } \\
\text { replacement }\end{array}$ & 650 & 5 & 1 \\
\hline B15\% & $\begin{array}{c}15 \% \text { brick by } \\
\text { wt of sand }\end{array}$ & 705 & 4.5 & 1 \\
\hline B20\% & $\begin{array}{c}20 \% \text { brick by } \\
\text { wt. of sand }\end{array}$ & 700 & 3.5 & 1 \\
\hline SAP0.5\% & $\begin{array}{c}0.5 \% \text { SAP by } \\
\text { wt. of cement }\end{array}$ & 700 & 4.5 & 1 \\
\hline
\end{tabular}



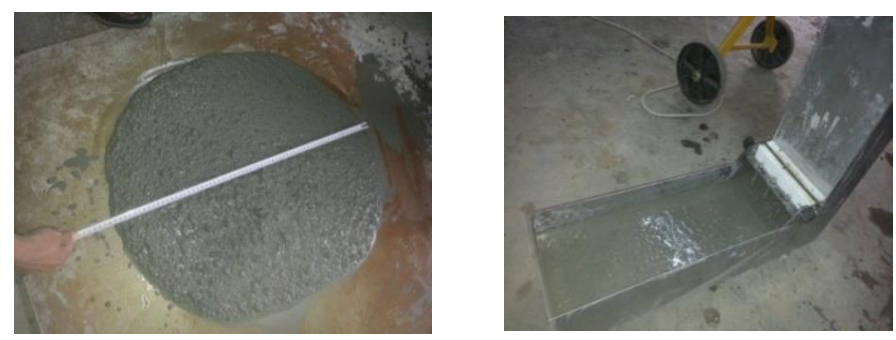

Fig. 2. (a) Slump flow

(b) $\mathbf{L}-$ Box

Table 10. Compressive strength results

\begin{tabular}{|c|c|c|c|c|}
\hline \multirow{3}{*}{$\begin{array}{c}\text { Mix } \\
\text { Description }\end{array}$} & \multirow{2}{*}{$\begin{array}{c}\text { Curing } \\
\text { method }\end{array}$} & \multicolumn{3}{|c|}{$\begin{array}{c}\text { Compressive } \\
\text { strength, N/mm }\end{array}$} \\
\cline { 3 - 5 } & & $\begin{array}{c}7 \\
\text { days }\end{array}$ & $\begin{array}{c}\mathbf{2 8} \\
\text { days }\end{array}$ & $\begin{array}{c}\mathbf{9 0} \\
\text { days }\end{array}$ \\
\hline \multirow{3}{*}{ Ref } & Water cured & 34 & 60 & 66 \\
\hline & Moist cured & - & 58 & 67 \\
\cline { 2 - 5 } & Air cured & - & 62 & 64 \\
\hline \multirow{3}{*}{ B15\% } & Water cured & 33.4 & 55 & 63 \\
\cline { 2 - 5 } & Moist cured & - & 56 & 68 \\
\cline { 2 - 5 } & Air cured & - & 59 & 64 \\
\hline \multirow{3}{*}{ B20\% } & Water cured & 31 & 58.2 & 65 \\
\cline { 2 - 5 } & Moist cured & - & 60.7 & 69.2 \\
\cline { 2 - 5 } & Air cured & - & 62 & 69 \\
\hline \multirow{3}{*}{ SAP0.5\% } & Water cured & 35.4 & 59 & 69 \\
\cline { 2 - 5 } & Moist cured & - & 61 & 71 \\
\cline { 2 - 5 } & Air cured & - & 66 & 73 \\
\hline
\end{tabular}

\subsection{Hardened SCC}

There is continuous increase in strength for all concrete specimens with the increasing of curing age as can be seen in Table 10, which is attributed to the increase of the bond strength between the concrete ingredients and the continuous hydration process which increased the dense hydrated calcium silicate in concrete with increased curing age.

Results also showed that the compressive strength of SCC increased by curing with water or moisture, however using internal curing enhancing this increment especially at later ages.

For water-cured specimens, the Ref mix always showed higher strength except the case of mix SAP.5\% at 90 days curing age.The change in compressive strength at 28 days is $-8,-3$, and -2 for mixes $\mathrm{B} 15 \%, \mathrm{~B} 20 \%$ and SAP. $5 \%$ respectively. This change for 90 days is $-5,-2$ and $+4 \%$ for mixes B $15 \%, \mathrm{~B} 20 \%$ and SAP. $5 \%$.

For moist and air curing procedures, the mixes B20\% and SAP.5\% showed their best enhancement for compressive strength. There were increments in strength for 28 and 90 days. At 28 days the change in strength is +5 and $+5 \%$ for moist-curing and is 0 and $+7 \%$ for aircuring for mixes B $20 \%$ and SAP. $5 \%$ respectively. At 90 days these figures change to +3 and $+6 \%$ for moistcuring and +8 and $+14 \%$ for air-curing for mixes B20\% and SAP.5\% respectively. It could be concluded that when there is a lack in curing water the internal curing by SAP is the best solution for this problem.

The improvement of the interfacial transition zone, raise hydration because of internal curing, and absence of shrinkage-induced microcracking will enhanced in strength. During mixing a $0.5 \%$ SAP addition permits an active control of geometric and thermodynamic properties of the water phase. The water is free in the formed SAP inclusions, and the initially added SAP particles governed the size and shape of the inclusions [21].The moisture can be seen clearly in SAP-concrete at early ages of curing (7days-broken cube), Figure 4.

Results of splitting tests of air-cured SCC showed the importance of using internal curing. The splitting strength increased by about $14 \%, 47 \%$ and $40 \%$ in $\mathrm{B} 15 \%, \mathrm{~B} 20 \%$ and $\mathrm{SAP} 0.5 \%$, respectively as compared to the reference mix. An enhancement was also observed in the Ultrasonic Pulse Velocity test and modulus of elasticity due to the high density of internally cured SCC concrete mixes.

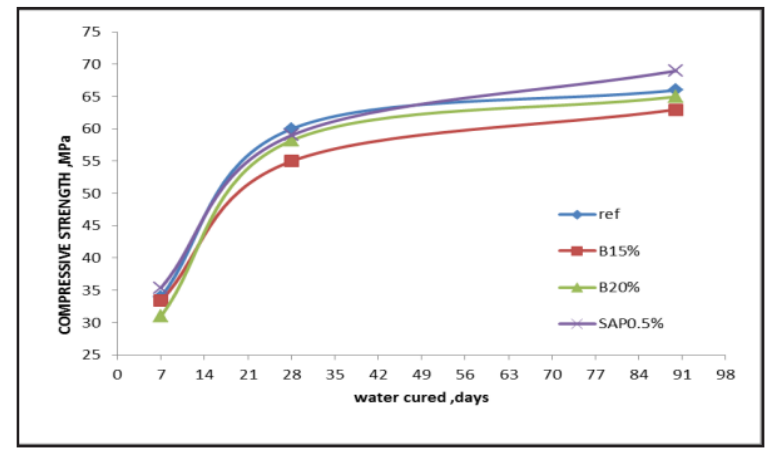

Fig.3. Compressive strength for all concrete mixes cured by water

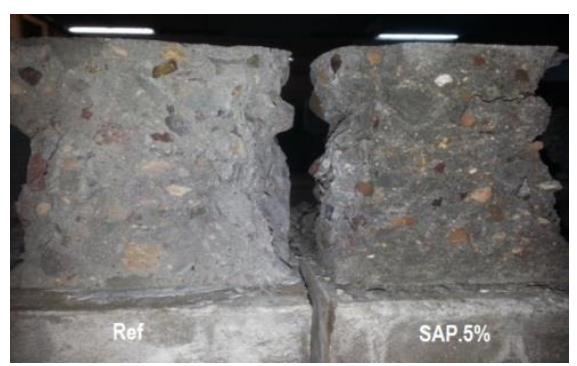

Fig. 4. Moisture in concrete due to SAP addition

Table 11. Splitting Strength, UPV, Density and Modulus of Elastisity

\begin{tabular}{|c|c|c|c|c|}
\hline $\begin{array}{c}\text { Concrete } \\
\text { Mixes }\end{array}$ & $\begin{array}{c}\text { Splitting } \\
\text { strength (MPa) } \\
90 \text { days }\end{array}$ & $\begin{array}{c}\text { Ultrasonic Pulse } \\
\text { Velocity } \\
90 \text { days }\end{array}$ & $\begin{array}{c}\text { Density } \\
\mathrm{kg} / \mathrm{m} 3\end{array}$ & $\begin{array}{c}\text { Modulus of } \\
\text { elasticity } \\
\text { GPa }\end{array}$ \\
\hline Ref & 2.5 & 4.47 & 2358.7 & 47.13 \\
\hline B15\% & 2.86 & 4.37 & 2368.4 & 45.229 \\
\hline B20\% & 3.69 & 4.545 & 2334.5 & 48.223 \\
\hline SAP0.5\% & 3.5 & 4.545 & 2361.4 & 48.779 \\
\hline
\end{tabular}




\section{Conclusions}

Based on the obtained results, the followings conclusions can be drawn:

1. Saturated Crushed brick has no adverse effect on selfcompactability tests of fresh SCC. SAP concrete needed a small addition of water due to high water absorption capacity of the SAP.

2. The replacement of fine aggregate by $20 \%$ crushed brick as internal curing material caused better enhancement in mechanical properties (strengths) of SCC than the case of $15 \%$ replacement.

3. The compressive strength of HPC containing $0.5 \%$ SAP yielded higher strength than HPC mixtures with or without saturated crushed brick.

4. Increments in splitting strength by about (14 and 47)

$\%$ were achieved due to adopting internal curing by $15 \%$ and $20 \%$ of crushed brick and $40 \%$ in SAP concrete.

5. Application of internal curing, results in higher ultrasonic pulse velocity values and density when compared with the normally cured concrete.

6. The most important benefit of using SAP as an internal curing is when the concrete is produced in hot weather; an increase in compressive strength by about $14 \%$ was achieved due to the application of internal curing by SAP for concrete left in air.

\section{References}

1. Okamura, H., "Self-Compacting High Performance Concrete," ACI Concrete International, Vol. 19, No. 7, pp.50-54 July (1997).

2. Erkmen, B., Shield, C. K., and French, C. E." SelfCompacting Concrete (SCC) for Prestressed Bridge Girders," Department of Civil Engineering University of Minnesota, October (2008).

3. ACI Committee 308,"Guide to curing concrete, 308R-01", ACI manual of concrete practice, (2001).

4. Bentz, D.P., Halleck, P.M., Grader, A.S., and Roberts, J.W., "Four-Dimensional X-ray Microtomography Study of Water Movement during Internal Curing" Proceedings of the International RILEM Conference - Volume Changes of Hardening Concrete: Testing and Mitigation, Eds. O.M. Jensen, P. Lura, and K. Kovler, RILEM Publications S.A.R.L., Bagneux, France, 1120,(2006).

5. Youssef, D., "The use of lightweight sand for internal curing and its effect on performance of HPC used for concrete infrastructures," Sherbrooke, Québec, Canada, June, (2013).

6. Cusson, D., "Effect of blended cements on effectiveness of internal curing in HPC," ACI SP256-9, (2009).

7. Mohammed, L. M., "improvement SCME properties of concrete with internal curing by using lightweight aggregate" MSc thesis, University of Baghdad, 2011.
8. Zohuriaan-Mehr, M. J. and Kabiri, K., " Superabsorbent Polymer Materials: A Review," Iranian Polymer Journal, 17 (6), 2008, 451-477.

9. Elliott, M., "Superabsorbent Polymers," Product Development Scientist for SAP, BASF, http://chimianet.zefat.ac.il/download/Super absorbant_polymers.pdf.

10. Hasholt, M., Seneka-Jespersen, M., and Jensen, O." Mechanical Properties of Concrete with SAP Part I: Development of Compressive Strength," In O. Jensen, M. Hasholt, \& S. Laustsen (Ed.), International RILEM Conference on Use of Superabsorbent Polymers and Other New Additives in Concrete. Bagneaux: RILEM Publications S.A.R.L. 2010.

11. Mechtcherine, V. and Reinhardt, H. W., "Application of superabsorbent polymers (SAP) in concrete construction,"state of the art report prepared by technical committee 225 -sap, Springer, 2011.

12. IQS No.5,"Portland cement", Central Organization for Standardization and Quality Control,Iraq, 1984.

13. IQS No.45," Aggregate from natural sources for concrete and building Construction, "Central Organization for Standardization and Quality Control,Iraq, 1984 .

14. ASTM C1240," Standard Specification for Silica Fume Used in Cementitious Mixtures", Annual Book of ASTM standard, Vol.04.02, 2005.

15. IQS No.25,"Clay building brick", Central Organization for Standardization and Quality Control, Iraq, 1988.

16. Emborg M., "Mixing and Transport ", Brite EuRam, Task 8.1, June 2000, pp.11-13.

17. EFNARC,"The European Guidelines for SelfCompacting Concrete Specification, Production and Use", 2005 .

18. BS 1881: Part 116, (1989), "Method for Determination of Compressive Strength of Concrete Cubes", British Standards Institution, (2003).

19. ASTM C496 "Standard Test Method for Splitting Tensile Strength for Cylindrical Concrete Specimens", American Society for Testing and Materials, (2004).

20. ASTM C597 "Standard Test Method for Pulse Velocity Through Concrete", American Society for Testing and Materials, (2002).

21. Jensen, O. M., "Use of Superabsorbent Polymers in Concrete", Concrete international, January, 2013. 